\title{
PEMANFAATAN MULTIMEDIA DALAM PEMBELAJARAN TRIGONOMETRI UNTUK PEMEROLEHAN KECAKAPAN INTELEKTUALDI KELAS X SMA NEGERI 1 SUNGAI RAYA
}

\author{
Rufini \\ SMAN 1 Sungai Raya \\ rufini_pipin@yahoo.com
}

\begin{abstract}
This research aim to to increase activity and result of learning student by exploiting multimedia in course of learning to teach in SMA Country 1 Great River. Peculiarly this research aim to 1) Analyzing how far Acquirement learn the student in intellectual efficiency domain at trig items after taught with the exploiting multimedia 2) Mendeskripsikan Respon student of at trig items after taught with the exploiting multimedia 3) Mendeskripsikan of Pattern aktifitas learn the student of at trig items after taught with the exploiting multimedia.Hereinafter pursuant to research result indicate that the exploiting multimedia in course of mathematics study of at trig items can improve the activity and result of learning student. With the active student percentage 51,51\%, complete percentage result of learning $78,78 \%$ and percentage of is make-up of motivation and also enthusiasm learn the student $96,9 \%$ by respon is positive pertained by a goodness. recommend from this research 1) Pursuant to research finding that exploiting multimedia in study of mathematics of trig items very effective, is therefore suggested for all education ladder exploit the multimedia in course of learning to teach 2) If we like to create the atmosphere learn more voluptuous exploit the lah multimedia in course of learning to teach 3) Expected to school head to can to equip, providing facility of related to study media of so that can be used at process learn to teach at school.
\end{abstract}

Key words: Multimedia, trigonometri, activity learn the student, respon of student and achievement learn student.

Kesulitan belajar yang tersebut mengalami kesulitan belajar dihadapi setiap siswa tidak sama atau matematika. Menurut Fowler (dalam bersifat individual. Hal ini nampak Pandoyo, 1997:1) matematika dalam sebaran nilai yang merupakan mata pelajaran yang menggambarkan prestasi belajar yang bersifat abstrak, sehingga dituntut beragam. Prestasi belajar siswa pada kemampuan guru untuk dapat mata pelajaran Matematika juga mengupayakan media yang tepat sangat beragam. Dari pengalaman sesuai dengan tingkat perkembangan mengajar selama 3 tahun terakhir mental siswa. Untuk itu diperlukan sekitar 30\% siswa memperoleh nilai model dan media pembelajaran yang di bawah batas Standar Ketuntasan dapat membantu siswa untuk Belajar (SKBM) dan 30\% siswa 
mencapai kompetensi dasar dan indikator pembelajaran.

Sampai saat ini masih banyak kesulitan-kesulitan yang dialami siswa dalam pelajaran matematika, salah satunya adalah memahami konsep pada pokok bahasan trigonometri. Akibatnya terjadi banyak kesulitan siswa dalam menjawab soal-soal ulangan umum,dan soal-soal Ujian Akhir Nasional yang berhubungan dengan trigonometri. Berdasarkan hasil wawancara dengan guru matematika Sekolah Menengah Atas Negeri 1 Sungai Raya, pada tanggal 20 Februari 2011, diperoleh informasi bahwa siswa masih mengalami kesulitan dalam mempelajari materi tersebut. Adapun beberapa penyebab siswa mengalami kesulitan belajar antara lain: materi prasyarat yang kurang dipahami oleh siswa, kurang aktifnya siswa dalam mencari dan mengumpulkan informasi yang diperlukan siswa untuk memahami materi tersebut, akibatnya hasil belajar mereka rendah.

Pada jenjang Sekolah Menengah Atas materi trigonometri diajarkan pada kelas X dan XI IPA, sehingga materi sebelumnya menjadi materi prasyarat terhadap materi yang akan datang. Sebagaimana yang dikemukakan oleh Bloom (dalam Nashar, 2004:24) menyatakan :'Kemampuan awal adalah pengetahuan, keterampilan dan kompetensi, yang merupakan prasyarat yang dimiliki untuk dapat mempelajari suatu pelajaran baru atau lebih lanjut." Pengalaman belajar yang telah dimiliki siswa besar pengaruhnya terhadap minat belajar. Pengalaman tersebut menjadi dasar untuk menerima pengalaman baru yang sangat membantu dalam minat belajar siswa. Sebagai contoh, seorang siswa akan sangat mudah dalam menguasai dan memahami materi pelajaran matematika, karena ia telah menguasai materi pelajaran matematika sewaktu Sekolah Menengah Pertama. Jadi, dapat dipahami bahwa penguasaan materi pelajaran matematika sangat dipengaruhi oleh pengalaman belajar matematika dijenjang pendidikan sebelumnya.

Menurunnya gairah belajar matematika,disebabkan oleh ketidaktepatan metodologis, juga berakar pada paradigma pembelajaran konvensional yang selalu mengunakan metode pengajaran klasikal dan ceramah, tanpa pernah diselingi berbagai metode yang variatif dan inovatif. Beberapa hal yang menonjol ialah siswa kurang berpartisipasi, kurang terlibat, dan tidak punya inisiatif serta kontribusi, baik secara intelektual maupun emosional. Pertanyaan dari siswa, gagasan ataupun pendapat jarang muncul. Jika pun ada pendapat yang muncul, jarang diikuti oleh gagasan lain sebagai respon. Kesulitan belajar siswa yang mengakibatkan kegagalan belajar ini perlu mendapatkan perhatian dan penanganan yang serius, yakni adanya inovasi pada proses pembelajaran. Oleh karena itu, perlu diperhatikan sebuah sistem pembelajaran 'baru' yang dapat memberdayakan siswa agar siswa lebih aktif dan termotivasi dalam proses kegiatan pembelajaran.

Selain itu di dalam mempelajari matematika siswa memerlukan konteks dan situasi yang berbeda sehingga diperlukan usaha guru untuk: (1) Menyediakan dan 
menggunakan berbagai alat peraga atau media pembelajaran yang menarik perhatian siswa (2) Memberikan kesempatan belajar matematika diberbagai tempat dan keadaan (3) Memberikan kesempatan menggunakan matematika untuk berbagai keperluan (4)Mengembangkan sikap menggunakan matematika sebagai alat untuk memecahkan masalah baik disekolah maupun dirumah (5) Menghargai sumbangan tradisi, budaya dan seni di dalam pengembangan matematika. Membantu siswa menilai sendiri kegiatan matematikanya.(Depdiknas, 2006:6). Dapat disimpulkan usaha guru dalam melakukan pembelajaran matematika harus bisa membuat situasi yang menyenangkan, memberikan alternatif penggunaan alat peraga atau multimedia yang bisa digunakan pada berbagai tempat dan keadaan, baik disekolah maupun dirumah.

Untuk pemahaman konsep pembelajaran matematik siswa mengalami kesulitan secara individual yang dimana memiliki cara pandang yang berbeda dalam memahami konsep-konsep baru yang diajarkan, berkaitan pada kawasan teknologi pembelajaran yang merupakan gabungan dari tiga aliran yang saling berkepentingan, yaitu media pendidikan, psikologi pembelajaran dan pendekatan sistem untuk pendidikan (Seels, 1979). Dalam perkembangan teknologi pembelajaran menggunakan tiga prinsip dasar yang perlu dijadikan acuan dalam pengembangan dan pemanfaatannya, yaitu: 1). pendekatan sistem (system approach), 2). berorientasi pada peserta didik (learner centered), dan 3). pemanfaatan sumber belajar semaksimal dan sebervariasi mungkin (utilizing learning resources) (Sadiman, 1984). Prinsip pendekatan sistem berarti bahwa setiap usaha pemecahan masalah pendidikan yang dilandasi konsep teknologi pembelajaran hendaknya menerapkan prinsip pendekatan sistem. Artinya memandang segala sesuatu sebagai sesuatu yang meneluruh (komprehensif) dengan segala komponen yang saling terintegrasi. Prisip berorientasi pada peserta didik, berarti bahwa usaha-usaha pendidikan, pembelajaran dan pelatihan hendaknya memusatkan perhatiannya pada peserta didik. Sedangkan prinsip ketiga yaitu pemanfaatan sumber belajar semaksimal dan sebervariasi mungkin, berarti peserta didik belajar karena berinteraksi dengan berbagai sumber belajar secara maksimal dan bervariasi.

Edgar Dale (1969) merupakan tokoh yang berjasa dalam pengembangan teknologi pembelajaran modern. Edgar Dale mengemukakan tentang kerucut pengalaman (cone of experience). Untuk dapat memaksimalkan proses belajar mengajar di kelas dalam kawasan teknologi pembelajaran ada lima domain yang dimana salah satunya adalah kawasan pemanfaatan. Pemanfaatan multimedia yaitu penggunaan yang sistematis dari sumber belajar. Proses pemanfaatan multimedia merupakan proses pengambilan keputusan berdasarkan pada spesifikasi desain pembelajaran. Misalnya bagaimana suatu media pembelajaran diperkenalkan atau ditindaklanjuti dan dipolakan sesuai 
dengan bentuk belajar yang diinginkan. Prinsip-prinsip pemanfaatan media juga dikaitkan dengan karakteristik peserta didik. Seseorang yang belajar mungkin memerlukan bantuan keterampilan visual atau verbal agar dapat menarik keuntungan dari praktek atau sumber belajar. Masalah pembelajaran menggunakan multimedia di Sekolah Menengah Atas kiranya merupakan alternatif yang tepat untuk memenuhi kebutuhan siswa, dan selanjutnya dapat meningkatkan aktifitas pembelajaran trigonometri.

$$
\text { Dominikus Catur Raharja }
$$
(2001:7) menyatakan:"Guru adalah kreator proses belajar mengajar. Guru adalah orang yang akan mengembangkan suasana bebas bagi siswa untuk mengkaji apa yang menarik minat, mengekpresikan ideide dan kreatifitasnya dalam batas norma-norma yang ditegakkan secara konsisten". Cara penyampaian pelajaran yang kurang menarik menjadikan siswa kurang berminat dan kurang bersemangat mengikutinya. Berdasarkan uraian diatas perlu kiranya suatu upaya dari guru mendapatkan media yang memanfaatkan multimedia untuk pemerolehan pemahaman materi trigonometri yang lebih baik. Pemanfaatan multimedia sebagai pembelajaran termasuk dalam salah satu kawasan teknologi pembelajaran, yaitu pemanfaatan media pembelajaran.

Pemilihan Sekolah Menengah Atas Negeri 1 Sungai Raya menjadi tempat penelitian berdasarkan beberapa pertimbangan antara lain :Nilai rata-rata pelajaran matematika pada Ujian Nasional lebih rendah dari nilai pelajaran lainHasil belajar siswa pada materi trigonometri rata-rata dibawah nilai KKM, sehingga belum mencapai ketuntasan dengan nilai KKM 60. Siswa yang tertampung pada program IPA relatif rendah, dari 800 siswa kelas XI dan XII Tahun Ajaran 2010/2011 yang tertampung pada program IPA berjumlah 160 siswa.Jumlah jam mengajar perminggu untuk guru mata pelajaran matematika melebihi 24 jam. Menurut Wingkel dalam Darsono (2000 : 4) menyatakan belajar adalah suatu aktivitas mental/psikis dalam interaksi aktif dengan lingkungan, yang menghasilkan perubahan dalam pengetahuan pemahaman, keterampilan dan sikap.

Teori pembelajaran yang dikemukakan oleh Gagne disebut dengan "teori pemrosesan informasi" (information processing theory) dan "teori-teori pembelajaran" (condition of learning). Asumsi yang mendasari teori Gagne adalah bahwa pembelajaran merupakan faktor yang sangat penting dalam perkembangan. Pengembangan merupakan hasil kumulatif dari pada pembelajaran. Hasil pembelajaran si individu merupakan kumpulan keseluruhan hasil-hasil pembelajaran sebelumnya yang saling terkait. Gagne (1979) berpendapat bahwa dalam pembelajaran terjadi proses penerimaan informasi untuk kemudian diolah sehingga menghasilkan keluaran dalam bentuk hasil pembelajaran. Dalam pemrosesan itu informasi itu terjadi adanya interaksi antara kondisikondisi internal dan kondisi-kondisi eksternal individu.

Menurut Gagne dalam Catharina Tri Ani (2004), belajar merupakan suatu system yang 
didalamnya terdapat unsur saling terkait sehingga menghasilkan perubahan prilaku. Menurut Gagne belajar bukan merupakan proses tunggal melainkan proses luas yang dibentuk oleh pertumbuhan dan perkembangan tingkah laku, dimana tingkah laku itu merupakan proses komulatif dari belajar. Artinya banyak keterampilan memberikan sumbangan bagi belajar keterampilan yang rumit. Pengertian belajar secara formal belajar adalah perubahan dalam disposisi atau kapabilitas manusia yang berlangsung selama atau semasa waktu dan tidak sematamata disebabkan oleh proses pertumbuhan. Perubahan itu berbentuk perubahan tingkah laku. Hal itu dapat diketahui dengan jalan membandingkan tingkah laku sebelum belajar dan tingkah laku yang diperoleh setelah belajar. Perubahan tingkah laku dapat berbentuk perubahan kapabilitas jenis kerjaan atau perubahan sikap, minat atau nilai.

Dengan multimedia pembelajaran, peserta didik dapat belajar sesuai kebutuhan, kecepatan, keluwesan, dapat memilih materi yang ingin diperoleh. Serta bisa digunakan secara individual dan dapat dilakukan secara berulang jika belum memahami materi tersebut. Terlihat keunggulan pemanfaatan teknologi dalam pembelajaran, walau bagi sebagian orang masih dianggap lebih banyak pembanjiran dari pada manfaat. Multimedia merupakan suatu sistem penyampaian dengan menggunakan berbagai jenis bahan belajar yang membentuk sebuah unit atau paket. Contohnya suatu modul belajar yang terdiri atas bahan cetak, bahan audio,dan bahan audio visual.
Kelebihan multimedia adalah siswa memiliki pengalaman yang beragam dari segala media, dapat menghilangkan kebosanan siswa karena media yang digunakan lebih bervariasi dan sangat baik untuk kegiatan belajar mandiri. Menurut Azhar Arsyad (2002:170) multimedia secara sederhana diartikan sebagai lebih dari satu media. Multimedia bisa berupa kombinasi antara teks, grafik, animasi, suara, dan video. Perpaduan dan kombinasi dua atau lebih jenis media ditekankan kepada kendali komputer sebagai pengerak keseluruhan gabungan media itu. Gabungan ini merupakan secara bersama-sama menampilkan informasi, pesan, atau isi pelajaran.

Kamus informasi dan teknologi mendefinisikan multimedia sebagai suatu PC, sistim dokumen, dan lainlain yang mengkombinasikan teks, grafik, suara, film atau media lain (Dudi Misky, 2005 :180). Definisi lain dari multimedia adalah pemanfaatan komputer membuat dan menggabungkan teks, grafik audio, gambar bergerak (video dan animasi) dengan menggabungkan link dan tool yang memungkinkan pemakai melakukan navigasi, berinteraksi, berkreasi, dan berkomunikasi (Suyanto, 2005). Multimedia yang dideskripsikan diatas, merupakan kombinasi dari teks, foto, seni grafis, animasi, dan elemen-elemen video yang dimanipulasi secara digital. Ketika orang mengizinkan pengguna akhir pemirsa dari proyek multimedia, mengontrol apa dan kapan elemen-elemen tersebut akan dikirimkan. Ketika menyediakan suatu struktur dari elemen-elemen yang terkait dimana pengguna dapat 
mengarahkannya, menerapkan multimedia.

Berdasarkan uraian diatas,maka judul penelitian ini adalah "Pemanfaatan Multimedia dalam Pembelajaran Trigonometri untuk Pemerolehan Kecakapan Belajar Intelektual dan Pemecahan Masalah pada Siswa Kelas X SMA Negeri I Sungai Raya “. Tujuan umum penelitian ini adalah "Untuk mengetahui hubungan antara aktivitas dan hasil belajar siswa ketika mengikuti proses pembelajaran materi trigonometri dikelas X SMA Negeri I Sungai Raya".

\section{Metode}

Metode yang digunakan dalam penelitian ini adalah penelitian eksperimen dengan bentuk PraEksperimental. Dimana PraEksperimental cocok untuk percobaan bahan-bahan pelajaran (Subana dan Sudrajat,2005:98). Adapun rancangan dari penelitian ini adalah dengan menggunakan rancangan One-Group Pretest-Posttest Design. Hal ini dikarenakan hasil perlakuan dapat diketahui lebih akurat, karena dapat membandingkan dengan keadaan sebelum diberikan perlakuan (Sugiyono, 2009:111). Adapun yang menjadi populasi dalam penelitian ini adalah siswa kelas X SMA Negeri 1 Sungai Raya Kab. Kubu Raya.

Sampel dalam penelitian ini adalah satu kelas X SMA Negeri 1 Sungai Raya. Untuk memilih sampel penelitian digunakan teknik sampling. Adapun teknik sampling yang digunakan adalah probability sampling dimana teknik pengambilan sampel yang memberikan peluang yang sama dari setiap unsur (anggota). Kemudian dengan menggunakan RandomSampling, hal ini dilakukan karena prestasi belajar matematika siswa kelas X SMA Negeri 1 Sungai Raya relatif sama yang dilihat dari rata-rata hasil ulangan harian bidang studi matematika dan dilakukan uji homogenitas menggunakan uji bartlett untuk mengetahui bahwa setiap kelas X SMA Negeri 1 Sungai Raya adalah homogen. Dari uji didapat sampelnya adalah kelas X A SMA Negeri 1 Sungai Raya Kab. Kubu Raya, dengan jumlah sample 33 siswa.

Teknik pengumpul data dalam
penelitian ini adalah teknik pengukuran (tes) dan komunikasi tak langsung (angket), Digunakannya teknik ini sesuai dengan metode yang digunakan yaitu penelitian eksperimen yang bertujuan untuk melihat hasil belajar, respon siswa, dan aktivitas belajar siswa. Pada proses belajar yang memanfaatkan multimedia. Tes yang dilakukan dalam penelitian ini berupa soal posttest yang berbentuk essay (uraian), Alasan digunakannya tes essay dalam penelitian ini karena mempunyai manfaat antara lain dapat menghindarkan sifat terkaan sehingga dapat melatih siswa untuk berfikir dan dapat mengukur kemampuan analitiknya.

Untuk dapat mendeskripsikan kegiatan belajar mengajar saat diterapkannya pembelajaran dengan pemanfaatan multimedia maka perlulah lembar pengamatan dijadikan sebagai alat (instrument) yang dapat membantu. Dimana lembar pengamatan yang digunakan bersifat terstruktur atau memiliki pedoman dalam bentuk pertanyaan. Dalam penggunaan lembar 
pengamatan aktivitas siswa ini pengamat mendeskripsikan jawabannya dengan pemberian skor 0 untuk aktivitas pasif dan skor 10 untuk aktivitas aktif dan dilakukan secara objektif. Lembar pengamatan aktivitas siswa yang digunakan dalam penelitian ini adalah valid setelah divalidasi.

Data yang diperoleh dari hasil tes kemudian diolah sesuai dengan langkah-langkah analisis data sebagai berikut :pemerolehan belajar kecakapan intelektual siswa maka hasil posttest diberi skor dan jika skor yang diperoleh telah mencapai kriteria ketuntasan minimal yang ditetapkan pihak sekolah. Siswa dikatakan tuntas secara individual apabila hasil belajar siswa (posttest) memperolah skor $\geq 60$. Hal ini ditetapkan dengan SKBM mata pelajaran matematika yang ditetapkan di SMA Negeri 1 Sungai Raya untuk kelas X yaitu 60. Sedangkan siswa tuntas secara klasikal apabila persentase ketuntasan hasil belajar siswa $\geq 75 \%$ dari siswa yang mendapat nilai $\geq 60$.

Adapun langkah-langkah perhitungan yang dilakukan adalah :

(a) Memberi skor hasil posttest siswa berdasarkan pedoman penskoran yang mana didasarkan pada suatu rubrik penskoran dengan kriteria yang sama untuk setiap butir soal, (b) Mengubahnya skor tersebut dalam bentuk nilai, (c) Menghitung jumlah siswa yang mendapat nilai $\geq 60$ dan menghitung persentasenya dengan rumus :

$$
\begin{aligned}
& P(n)=\frac{n}{N} \times 100 \% \\
& \text { Nilai }=\frac{\text { Skor yang diperoleh siswa }}{\text { Skor maksimum }} \times 100
\end{aligned}
$$

Keterangan:

$P(n)=$ Persentase jumlah siswa

$\mathrm{n}=$ Jumlah siswa yang dikonversi dalam persentase

$\mathrm{N}=$ Total siswa

Suatu kelas dikatakan tuntas jika terdapat $\geq 75 \%$ dari jumlah siswa yang memperolah nilai $\geq 60$, sebaliknya untuk yang tidak tuntas (d) Menghitung peningkatan hasil belajar siswa akan digunakan uji peningkatan rata-rata menggunakan rumus Gain Ternormalisasi sebagai berikut:

$(\mathrm{g})=\frac{\text { skor posttert-skor pretest }}{\text { skor maksimum-skor prətest }}$

Dengan kriteria indeks gain pada Tabel 1.

Tabel 1. Kriteria indeks gain.

\begin{tabular}{|c|c|}
\hline Skor Gain & Interpretasi \\
\hline $\mathrm{g}>0,7$ & Tinggi \\
\hline $0,3<\mathrm{g}<0,7$ & Sedang \\
\hline $\mathrm{g} \leq 0,3$ & Rendah \\
\hline
\end{tabular}

(Hake, 1999)

Untuk mengetahui, mengkaji dan mendeskripsikan aktivitas siswa, hasil pengamatan dilakukan selama pembelajaran berlangsung melalui lembar pengamatan aktivitas siswa yang diamati oleh dua orang pengamat. Siswa dikatakan aktif apabila siswa telah melakukan kegiatan yang sesuai dengan aspek yang diamati pada lembar pengamatan aktivitas siswa.

Dengan persentase keaktifan sebagai berikut :

$\begin{array}{ll}90 \%-100 \% & \text { Sangat Aktif } \\ 80 \%-89 \% & \text { Aktif } \\ 70 \%-79 \% & \text { Cukup Aktif } \\ 60 \%-69 \% & \text { Kurang Aktif }\end{array}$

$\leq 59 \%$ SangatKurang Aktif

Untuk menjawab hipotesis ; "Terdapat hubungan positif antara aktivitas dan perolehan belajar siswa 
setelah pembelajaran dengan pemanfaatan multimedia" menggunakan perhitungan teknik korelasi Phi $(\Phi)$ sebagai berikut:

$\Phi=\frac{(\mathrm{ad}-\mathrm{bc})}{\sqrt{(\mathrm{a}+\mathrm{b})(\mathrm{a}+\mathrm{c})(\mathrm{b}+\mathrm{d})(\mathrm{c}+\mathrm{d})}}$

(Subana dan Sudrajat, 2000:160)

Nilai dari korelasi Phi $(\Phi)$ dibandingkan dengan korelasi table. $\mathrm{db}=\mathrm{N}-2$

Jika $\Phi>r_{\text {tabel }}$ maka hipotesis diterima. Hipotesisnya yaitu : "Terdapat hubungan positif antara aktivitas dan perolehan belajar siswa setelah pembelajaran dengan pemanfaatan multimedia."

\section{Hasil dan Pembahasan}

Pada prapenelitian dilakukan observasi dan wawancara kepada responden yakni guru matematika SMA Negeri 1 Sungai Raya kelas X pada tanggal 20 Februari 2011. Dan ditemukan beberapa hal berikut : (a) Proses pembelajaran pada mata pelajaran matematika kelas $\mathrm{X}$ umumnya masih menggunakan metode konvensional klasikal dan ceramah, yaitu guru menerangkan materi dan siswa mencatat serta bertanya. Serta materi yang tergolong sulit adalah trigonometri.

Tabel 2. Hasil persentase aktivitas siswa prapenelitian.

\begin{tabular}{|c|c|c|c|c|c|}
\hline Siswa & $\%$ & Ket & Siswa & $\%$ & Ket \\
\hline A1 & 80 & Aktif & M3 & 80 & Aktif \\
\hline A 2 & 60 & Pasif & M4 & 60 & Pasif \\
\hline A3 & 60 & Pasif & M5 & 60 & Pasif \\
\hline A4 & 40 & Pasif & O1 & 60 & Pasif \\
\hline A5 & 40 & Pasif & $\mathrm{O} 2$ & 20 & Pasif \\
\hline A6 & 80 & Aktif & $\mathrm{P} 1$ & 40 & Pasif \\
\hline A7 & 20 & Pasif & $\mathrm{R} 1$ & 40 & Pasif \\
\hline D1 & 40 & Pasif & $\mathrm{R} 1$ & 20 & Pasif \\
\hline D2 & 60 & Pasif & $\mathrm{S} 1$ & 40 & Pasif \\
\hline E1 & 80 & Aktif & $\mathrm{S} 2$ & 40 & Pasif \\
\hline $\mathrm{F} 1$ & 40 & Pasif & $\mathrm{S} 3$ & 40 & Pasif \\
\hline $\mathrm{F} 2$ & 60 & Pasif & $\mathrm{S} 4$ & 20 & Pasif \\
\hline I1 & 80 & Aktif & S5 & 60 & Pasif \\
\hline $\mathrm{K} 1$ & 60 & Pasif & $\mathrm{T} 1$ & 80 & Aktif \\
\hline $\mathrm{L} 1$ & 60 & Pasif & $\mathrm{T} 2$ & 40 & Pasif \\
\hline M1 & 60 & Pasif & W1 & 40 & Pasif \\
\hline M2 & 60 & Pasif & & & \\
\hline \multicolumn{3}{|c|}{ Jumlah Siswa Aktif } & \multicolumn{3}{|c|}{6} \\
\hline \multicolumn{3}{|c|}{ Jumlah Siswa Pasif } & \multicolumn{3}{|c|}{27} \\
\hline
\end{tabular}

(b) Penggunaan media pada mata pelajaran matematika masih jarang digunakan oleh guru. Selama ini hanya sebatas media gambar dengan kata lain guru belum 
pernah menggunakan multimedia. (c) Respon siswa terhadap mata pelajaran matematika kurang baik terlihat pada saat diminta maju kedepan untuk Persentase keaktifan siswa selama mengikuti pembelajaran matematika dapat dilihat pada Tabel 2. Berdasarkan tabel diatas dapat dilihat bahwa 6 siswa $(18,18 \%)$ aktif selama kegiatan belajar mengajar berlangsung dan 27 siswa $(81,81 \%)$ pasif selama kegiatan belajar mengajar berlangsung. Gambaran secara umum kondisi belajar mengajar di kelas XA SMA Negeri 1 menyelesaikan soal tidak berani dan pada saat diberikan PR banyak yang tidak mengerjakan, dengan alasan tidak mengerti cara penyelesaiannya. Sungai Raya yaitu $81,81 \%$ cara belajar siswa pasif dimana sebagian besar siswa hanya mendengarkan dan mencatat penjelasan guru, tidak terlalu banyak siswa yang aktif bertanya dan menyelesaikan latihan soal-soal yang diberikan oleh guru. Untuk melihat lebih jelas sebaran data aktivitas dan hasil belajar siswa disajikan dalam histogram (Gambar 1).

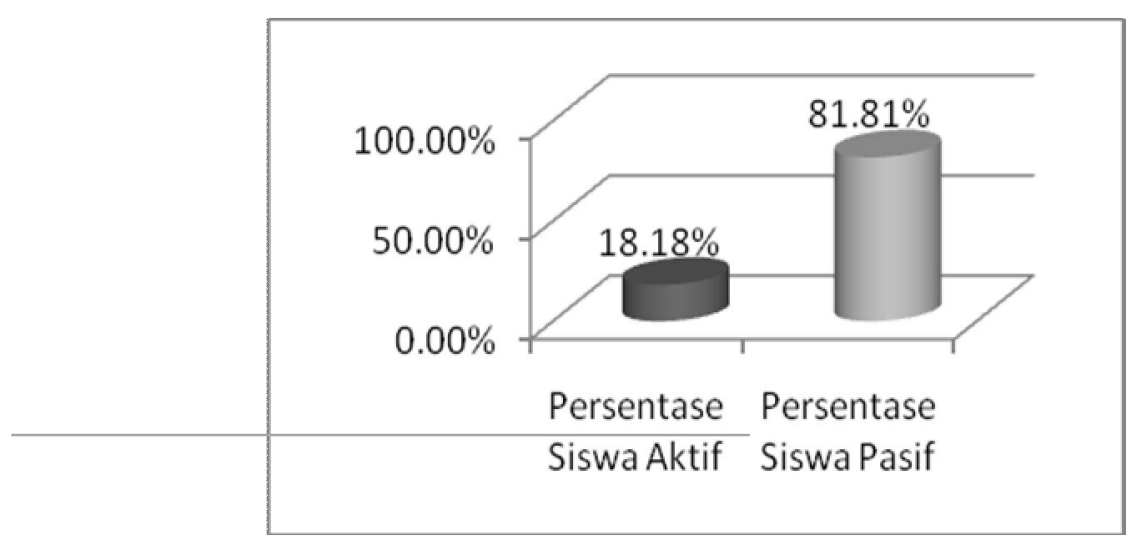

Gambar 1. Grafik hasil persentase aktivitas siswa prapenelitian.

Pada penelitian ini berlandaskan pada teori belajar Gagne pencapaian kecakapan intelektual siswa menyangkut pada tiga aspek yaitu:

1. Peningkatan hasil belajar

2. Meningkatnya motivasi serta minat belajar dan,

3. perubahan tingkah laku untuk memeperoleh kemampuan.

Data hasil belajar siswa diperoleh dengan memberikan pretest sebagai tes awal, dan posttest sebagai test setelah siswa diberikan pembelajarandengan pemanfaatan multimedia. Kemudian dilihat ketuntasan hasil belajar siswa diperoleh dari hasil post-test dengan cara membandingkan dengan SKBM yang digunakan oleh SMA Negeri 1 Sungai Raya pada mata pelajaran Matematika yaitu 60. Sehingga siswa dikatakan tuntas belajar apabila nilai post-test lebih besar atau sama dengan 60. Berikut langkah-langkah yang dilakukan:

1. Memberi skor dan nilai

Memberi skor siswa setiap butir soal yang dijawab dengan benar sesuai dengan kunci jawaban dengan menggunakan rubrik 
penskoran dengan rentang skor 02. Setelah diperoleh skor hasil test siswa diberikan nilai dengan rumus:

$$
N=\frac{\text { Skor yang di peroleh siswa }}{\text { Skor maksimum }} \times 100
$$

2. Menghitung persentase siswa yang memperoleh nilai $\geq 60$

Adapun hasil posttest dapat dilihat pada Tabel 3.

$$
\mathrm{P}(\mathrm{n})=\frac{n}{N} \times 100 \%=\frac{26}{33} \times 100 \%=
$$

$78,8 \%$
Keterangan:

$\mathrm{P}(\mathrm{n})=$ Persentase siswa yang memperoleh nilai $\geq 60$.

$\mathrm{n} \quad=$ Jumlah siswa yang memperolah nilai $\geq 60$.

$\mathrm{N}$ = Jumlah siswa secara keseluruhan.

Dari perhitungan di atas diperoleh kesimpulan bahwa hasil belajar siswa setelah diberikan pembelajaran dengan pemanfaatan multimediatuntas secara klasikal. Karena persentase ketuntasan hasil belajar siswa sebanyak $78,8 \%$ dari ketuntasan klasikal $75 \%$.

\begin{tabular}{|c|c|c|c|c|c|}
\hline \multirow{2}{*}{$\begin{array}{l}\text { Kode } \\
\text { Siswa }\end{array}$} & \multicolumn{2}{|c|}{ Posttest } & \multirow{2}{*}{$\begin{array}{l}\text { Kode } \\
\text { Siswa }\end{array}$} & \multicolumn{2}{|c|}{ Posttest } \\
\hline & Skor & Ket & & Skor & Ket \\
\hline A1 & 60 & Tuntas & M3 & 95 & Tuntas \\
\hline $\mathrm{A} 2$ & 75 & Tuntas & M4 & 65 & Tuntas \\
\hline A3 & 60 & Tuntas & M5 & 65 & Tuntas \\
\hline A4 & 60 & Tuntas & $\mathrm{O} 1$ & 60 & Tuntas \\
\hline A5 & 60 & Tuntas & $\mathrm{O} 2$ & 45 & Tidak Tuntas \\
\hline A6 & 60 & Tuntas & $\mathrm{P} 1$ & 80 & Tuntas \\
\hline A7 & 45 & Tidak Tuntas & $\mathrm{R} 1$ & 60 & Tuntas \\
\hline D1 & 65 & Tuntas & $\mathrm{R} 2$ & 45 & Tidak Tuntas \\
\hline D2 & 75 & Tuntas & $\mathrm{S} 1$ & 50 & Tidak Tuntas \\
\hline E1 & 60 & Tuntas & $\mathrm{S} 2$ & 85 & Tuntas \\
\hline $\mathrm{F} 1$ & 45 & Tidak Tuntas & S3 & 55 & Tidak Tuntas \\
\hline $\mathrm{F} 2$ & 80 & Tuntas & S4 & 45 & Tidak Tuntas \\
\hline I1 & 95 & Tuntas & S5 & 60 & Tuntas \\
\hline $\mathrm{K} 1$ & 80 & Tuntas & $\mathrm{T} 1$ & 70 & Tuntas \\
\hline L1 & 75 & Tuntas & $\mathrm{T} 2$ & 65 & Tuntas \\
\hline M1 & 70 & Tuntas & W1 & 85 & Tuntas \\
\hline M2 & 60 & Tuntas & & & \\
\hline \multicolumn{3}{|c|}{ Rata-rata } & \multicolumn{3}{|c|}{65,3} \\
\hline \multicolumn{3}{|c|}{ Jumlah Tuntas } & \multicolumn{3}{|c|}{26} \\
\hline \multicolumn{3}{|c|}{ Jumlah Tidak Tuntas } & \multicolumn{3}{|c|}{7} \\
\hline
\end{tabular}

Tabel 3. Hasil post-test. 
3. Menghitung peningkatan hasil belajar siswa

Untuk mengetahui peningkatan hasil tes belajar siswa akan digunakan uji Gain Ternormalisasi dengan rumus :

$\mathrm{g}=\frac{\text { skor posttest }- \text { skor pretest }}{\text { skor maksimum-skor pretest }}$

$g=\frac{431-283}{660-283}=0,39$

Dengan kriteria indeks gain sebagai berikut :

Tabel 4. Indeks Gain Ternormalisasi

\begin{tabular}{cc}
\hline Skor Gain & Interpretasi \\
\hline $\mathrm{g}>0,7$ & Tinggi \\
\hline $0,3<\mathrm{g}<0,7$ & Sedang \\
\hline $\mathrm{g} \leq 0,3$ & Rendah \\
\hline
\end{tabular}

Dari hasil diatas dan tabel 3 indeks gain ternormalisasi dapat disimpulkan bahwa peningkatan hasil belajar siswa pada materi trigonometri dengan pemanfaatan multimedia tergolong sedang.

Berdasarkan hasil jawaban siswa bahwa respon siswa terhadap pembelajaran dengan pemanfaatan multimedia adalah tergolong baik. dimana pemanfaatan multimedia dapat meningkatkan minat dan motivasi belajar siswa serta siswa menjadi lebih aktif.

Setelah data teruji normal dan homogen maka dilakukan pengujian Hipotesis Dengan Teknik Korelasi Phi $(\Phi)$.

Tabel 4. Uji korelasi phi $(\varphi)$

\begin{tabular}{llll}
\hline & Aktif & Pasif & Jumlah \\
\hline Tuntas & ${ }^{\mathrm{a}} 17$ & ${ }^{\mathrm{b}} 8$ & 25 \\
\hline $\begin{array}{l}\text { Tidak } \\
\text { Tuntas }\end{array}$ & ${ }^{\mathrm{c}} 0$ & ${ }^{\mathrm{d}} 8$ & 8 \\
\hline Jumlah & 17 & 16 & 33 \\
\hline
\end{tabular}

Rumusan Hipotesis :

$\mathrm{H}_{\mathrm{o}}$ : Tidak terdapat hubungan positif antara aktifitas dan perolehan belajar siswa setelah pembelajaran dengan pemanfaatan multimedia.

$\mathrm{H}_{\mathrm{a}}$ : Terdapat hubungan positif antara aktifitas dan perolehan belajar siswa setelah pembelajaran dengan pemanfaatan multimedia.

Rumus :

$$
\begin{aligned}
\Phi & =\frac{(a d-b c)}{\sqrt{(a+b)(a+c)(b+d)(c+d)}} \\
\Phi & =\frac{(17)(8)-(8)(0 !}{\sqrt{(17+8)(17+0)(8+8)(0+8)}} \\
& =0,583
\end{aligned}
$$

Jadi, $\Phi=0,583$

Koefisien korelasi $\Phi$ dapat diinterpretasikan dengan cara yang sama dengan menganggap $\Phi$ sama dengan $\mathrm{r}_{\mathrm{xy}}$ product moment. $\mathrm{db}=\mathrm{N}$ $-2=33-2=31$, dengan $\alpha=0,05$ $; r_{\text {tabel }}=0,344$, dengan demikian $\Phi$ yang besarnya 0,583 lebih besar daripada $r_{\text {tabel }}$ yaitu 0,344, sehingga disimpulkan:

$\mathrm{H}_{\mathrm{o}}$ ditolak dan $\mathrm{H}_{\mathrm{a}}$ diterima yaitu Terdapat hubungan positif antara aktifitas dan perolehan belajar siswa setelah pembelajaran dengan pemanfaatan multimedia.

Dari hasil wawancara menunjukkan secara umum minat belajar siswa kurang baik terhadap mata pelajaran matematika hal tersebut dikarenakan guru masih memakai paradigma lama yakni teacher centered dalam proses pembelajaran. Sehingga metode pembelajaran masih menggunakan ceramah, guru menerangkan diiringi dengan mencatat bagian penting dari materi atau mencatat sesuai perintah guru. Perilaku pembelajaran ini membuat siswa jenuh, pasif dan 
kurang perhatian terhadap proses pembelajaran yang sedang berlangsung. Sudah tentu mengakibatkan hasil belajar yang kurang maksimal. Namun demikian, pada pengamatan kelas yang peneliti lakukan, hal ini terkadang cukup bisa teratasi dikarenakan kemampuan guru yang pandai menyampaikan materi atau penguasaan kelas yang cukup baik.

Langkah peneliti selanjutnya adalah menggali informasi tentang pemanfaatan multimedia dalam proses pembelajaran yang dilakukan guru mata pelajaran matematika di kelas X SMA Negeri 1 Sungai Raya. Dari hasil wawancara diketahui bahwa guru masih jarang menggunakan media pembelajaran. Selama ini media pembelajaran yang digunakan hanya sebatas media gambar. Hal tersebut dikarenakan guru mengalami kesulitan dalam mencari media pembelajaran yang dapat memenuhi kebutuhan individual siswa kelas X SMA Negeri 1 Sungai Raya, untuk itu guru sangat berharap akan adanya ragam multimedia pembelajaran matematika termasuk pemanfaatan multimedia yang digunakan peneliti. Serta juga menurut pemaparan guru, multimedia pembelajaran matematika belum pernah digunakan ketika proses pembelajaran matematika dilaksanakan disetiap kelas X, XI dan XII pada tingkat SMA/ sederajat. Pada hal guru menyadari bahwa media menjadi bagian penting dalam meningkatkan proses dan hasil dalam pembelajaran.

Selanjutnya $\quad$ peneliti
menanyakan seputar materi
pembelajaran matematika yang paling
mendasar yang penting untuk

dikuasai oleh siswa, materi tersebut adalah trigonometri. Dari hasil observasi prapenelitian diketahui persentase siswa aktif dan pasif, hasil keterhubungan antara tingkat aktivitas siswa dengan ketuntasan hasil belajar siswa adalah dimana siswa aktif tidak tuntas 3\% sedangkan siswa pasif tidak tuntas $30 \%$ terlihat siswa yang pasif lebih banyak yang tidak tuntas hasil belajarnya. Untuk siswa aktif yang tuntas $15 \%$ sedangkan siswa pasif tuntas $52 \%$ terlihat siswa pasif lebih banyak yang tuntas hal tersebut dikarenakan penyampaian materi oleh guru sudah cukup baik, sebagian besar siswa sudah terbiasa dengan proses belajar yang dilakukan guru dengan metode konvensional, namun dapat teramati pula ketuntasan yang dicapai dengan nilai yang kurang maksimal. Hal tersebut yang menjadi pertimbangan bahwa pentingnya pemanfaatan multimedia untuk memaksimalkan hasil belajar siswa atau perolehan kecakapan intelektual siswa.

Kecakapan intelaktual menurut Gagne adalah kecakapan penerapan konsep matematik dalam penyelesaian masalah, untuk mengukur sejauh mana pemerolehan kecakapan intelektual siswa setelah pemanfaatan multimedia pada pembelajaran matematika digunakan instrument pengukuran Pretest dan Postest dalam bentuk soal uraian, dengan penilaian berdasarkan kriteria umum rubrik penskoran, dengan persentase siswa yang memperoleh nilai $\geq 60$ sebesar $78,78 \%$ maka ratarata siswa tuntas secara klasikal, hasil dari uji gain ternormalisasi dengan $\mathrm{g}$ $=0,39$ peningkatan hasil belajar tergolong sedang, dari hasil tersebut dapat dinyatakan bahwa rata-rata 
siswa kelas XA SMA Negeri 1 Sungai Raya pemerolehan kecakapan intelektual sudah pada pemahaman konsep.

Respon siswa terhadap pembelajaran matematika pada materi trigonometri dengan pemanfaatan multimedia tergolong baik. dimana pemanfaatan multimedia dapat meningkatkan minat dan motivasi belajar siswa.Untuk memaksimalkan pemahaman konsep yang diterima oleh siswa dari suatu proses pembelajaran, ditinjau dari aspek aktivitas yakni seberapa aktifkah siswa dalam mengkonstruksi pemahamannya sendiri. Kaitan dalam penelitian ini aktivitas belajar siswa dibagi menjadi dua bagian yaitu siswa aktif dan siswa pasif. Untuk siswa aktif rentang persentase aktifitas $61 \%$ - $100 \%$, untuk siswa pasif $0 \%-60 \%$. Melihat dari perbandingan aktivitas belajar siswa dapat disimpulkan bahwa pembelajaran matematika dengan pemanfaatan multimedia secara umum membuat siswa aktif dalam belajar.

Dengan beberapa data hasil observasi prapenelitian, proses penelitian diawali dengan dilakukannya Pretest. Dengan bentuk soal uraian, disini materi yang terkait pada soal pretest adalah trigonometri dimana materi tersebut belum dipelajari siswa, tetapi tidak menutup kemungkinan terdapat beberapa siswa yang sudah mempelajarinya baik itu belajar sendiri atau mendapatkannya di bimbingan belajar tertentu. Hasil pretest digunakan sebagai tolak ukur peningkatan hasil belajar siswa. Adapun hasil yang diperoleh dari pengolahan data pretest, didapat informasi bahwa rata-rata hasil pretest pada kelas eksperimen sebesar 42,9 yang tergolong gagal dengan standar deviasi 7,4. Hal ini terjadi karena pengetahuan siswa tentang materi masih kurang.

Selama perlakuan atau proses belajar mengajar berlangsung, kegiatan belajar diawali dengan membuka pelajaran, menyampaikan tujuan pembelajaran, apersepsi dan memotivasi belajar siswa. Selanjutnya pemaparan konsep trigonometri dengan memanfaatkan multimedia berupa laptop, sound system, layar LCD, infokus. Dengan software yang memuat materi trigonometri tersimpan dalam Compact Disc (CD). Tampilan dari isi pemaparan materi trigonometri menggunakan warnawarna yang bervariasi, gambar dan animasi hal tersebut menciptakan suasana belajar yang inovatif. Teramati perhatian siswa terhadap pembelajaran yang sedang berlangsung cukup besar dan siswa sebagian besar antusias, pemaparan ini hanya membutuhkan waktu selama 10 menit.

Setelah memaparkan konsep materi trigonometri, selanjutnya memberikan suatu permasalahan kepada siswa yang berkaitan dengan materi trigonometri pada kehidupan sehari-hari untuk didiskusikan. Siswa aktif diskusi dan melakukan tanya jawab baik itu sesama siswa maupun dengan guru sebagai fasilitator. Terdapat beberapa siswa meminta guru untuk mengulang beberapa tampilan yang sudah ditayangkan. Hingga diskusi berakhir siswa merangkum hasil dari pembelajaran. Guru memberikan soal evaluasi dan PR. Adapun beberapa hal yang mengganggu proses belajar mengajar yang sedang berlangsung yaitu adanya siswa yang izin pergi ke WC, 
dan yang izin keluar untuk kepentingan urgen lainnya.

Setelah perlakuan dilakukanlah posttest dilaksanakan 2 hari setelah perlakuan diberikan kepada siswa, oleh karena itu ada beberapa faktor yang tidak dapat dikontrol oleh peneliti. Dengan demikian dapat dikatakan hasil belajar yang diperoleh siswa dipengaruhi faktor di luar perlakuan tetapi bukan berarti bahwa pembelajaran matematika dengan pemanfaatan multimedia tidak memberikan kontribusi dalam meningkatkan hasil belajar siswa. Berdasarkan hasil pengolahan data menunjukkan bahwa nilai rata-rata post-test $(x)=65,3$ dengan standar deviasi $(\mathrm{SD})=13,9$ pada kelas Eksperimen. Ini menunjukkan bahwa setelah diberikan perlakuan model pembelajaran matematika dengan pemanfaatan multimedia pada materi trigonometri tergolong baik.

Temuan selanjutnya dari 33 orang siswa pada kelas eksperimen yang diberikan perlakuan, 26 orang siswa berhasil mencapai ketuntasan belajar. Ini berarti persentase ketuntasan sebesar 78,78\%, maka hasil belajar dikatakan tuntas secara klasikal. Hal ini sesuai dengan pendapat Abdullah (Darawati, 2005:36) bahwa ketuntasan hasil belajar secara klasikal yaitu suatu kelas dikatakan tuntas apabila $\geq 75 \%$ siswa telah mencapai ketuntasan belajar. Pemberian angket dilakukan untuk mengetahui respon siswa terhadap pembelajaran pemanfaatan multimedia. Dari hasil jawaban siswa pada angket, diketahui bahwa respon siswa terhadap pembelajaran pemanfaatan multimedia adalah baik yaitu $87,3 \%$, karena siswa yang merasa senang selama mengikuti kegiatan pembelajaran pemanfaatan multimedia sebesar $100 \%$, siswa yang merasa bertambah minatnya selama mengikuti pembelajaran pemanfaatan multimedia96,9\%, siswa yang merasa bertambah pemahamannya selama mengikuti pembelajaran pemanfaatan multimedia sebesar $100 \%$, siswa yang setuju jika semua pokok bahasan diajarkan dengan menggunakan pembelajaran pemanfaatan multimedia sebesar $81,8 \%$, dan siswa yang setuju jika semua mata pelajaran diajarkan dengan menggunakan pembelajaran pemanfaatan multimedia sebesar 54,5\%. Dari hasil yang didapat, respon siswa terhadap pelaksanaan pembelajaran pemanfaatan multimediatergolong baik karena pembelajaran ini memberikan motivasi dan kerjasama serta interaksi terhadap sesama, siswa tidak lagi jenuh dengan pembelajaran walaupu masih banyak dari kemampuan siswa yang belum berkembang.

Selanjutnya, dari hasil analisis tentang aktivitas siswa selama pembelajaran berlangsung yang diberikan pembelajaran dengan pemanfaatan multimedia, diperoleh informasi bahwa tingkat aktivitas siswa sebesar $51,51 \%$ sedangkan siswa yang pasif sebesar $48,48 \%$. Dikategorikan aktif karena persentase perilaku aktif lebih besar daripada persentase perilaku pasif. Adapun siswa yang berperilaku aktif dalam kategori mendengarkan penjelasan guru dalam pembelajaran, memperhatikan demonstrasi yang dilakukan oleh guru, Mengerjakan soal/memecahkan soal dengan bantuan media pembelajaran, aktif Melakukan tanya jawab, Mengambil rangkuman/kesimpulan. 
Dengan kata lain, selama pembelajaran dengan menerapkan model pembelajaran matematika dengan pemanfaatan multimedia siswa aktif dalam melakukan kegiatan-kegiatan yang terdapat dalam proses pembelajaran, terutama yang sangat dominan yaitu siswa aktif merangkum hasil pembelajaran yang telah dipelajari dan menyimak penjelasan dari guru. Dari hasil pengamatan peneliti selama berlangsungnya pembelajaran menunjukkan bahwa siswa dikategorikan aktif dikarenakan siswa senang terhadap cara belajar pembelajaran matematika dengan pemanfaatan multimedia dan berkonteks lokal. Dari hasil pengujian hipotesis tentang terdapat hubungan positif antara aktifitas belajar dengan hasil belajar siswa, hipotesis tersebut disimpulkan diterima, hal tersebut selaras dengan pernyataan bahwa pengetahuan bukanlah gambaran dari dunia kenyataan yang yang ada. Pengetahuan selalu merupakan akibat dari suatu konstruksi kognitif kenyataan melalui kegiatan seseorang (Paul Suparno, 1997). Walaupun tidak menutup kemungkinan siswa yang aktif dalam belajar tetapi hasil belajarnya masih belum maksimal.

\section{Simpulan dan Saran}

Secara umum dapat disimpulkan bahwa penerapan pembelajaran dengan pemanfaatan multimedia pada materi trigonometri di kelas X SMA Negeri 1 Sungai Raya dapat memberikan konstribusi positif terhadap perolehan kecakapan intelektual siswa. Diharapkan kepada pimpinan sekolah untuk dapat melengkapi, menyediakan fasilitas yang berkaitan dengan media pembelajaran agar dapat digunakan pada proses belajar mengajar di sekolah.

\section{Daftar Pustaka}

Arief S. Sadiman, et al. (2006). Media pendidikan:

Pengertian, pengembangan dan pemanfaatannya. Jakarta: PT Raja Grafindo Persada.

Ariesto Hadi Sutopo. (2003). Multimedia interaktif dengan flash. Yogyakarta: Graha llmu.

Arsyad, azhar, 2002. Media pembelajaran, Jakarta : PT. Rajangrafindo Persada

Chtharina Tri Ani. (2004). Psikologi Belajar. Semarang : Unnes Press.

Constantinescu, A. I. (2010). Using technology to assist in vocabulary acquisition and reading comprehension. The Internet TESL Journal, Vol. XIII, No. 2, April 2010. Diambil tanggal 7 April 2010, dari http://itesli.org/Articles/Const antinescu-Vocabulary.html

Darsono. (2000). Belajar dan Pembelajaran. Semarang : IKIP Semarang Press.

Depdiknas. (2006). Peraturan Menteri Pendidikan Nasional RI Nomor 22, Tahun 2006, tentang Standar Isi untuk Satuan Pendidikan Dasar dan Menengah.

Dominikus Catur Raharja. (2001). Kesesuaian Pendidikan Bakat Menentukan Prestasi Siswa. Jakarta : Balai Pustaka 
Dudi Misky. (2005). Kamus Informasi dan Teknologi. Jakarta : Edsa Mahkota.

Edgar Dale. (1969). Audiovisual Methos in Teaching. New York: The Dryden Press

Gagne, R. M. \& Briggs, L. J. (1979). Principle of instructional design $\left(2^{\text {nd }}\right.$ ed.). New York: Holt, Rinenart and Winston.

Hake. (1999). Analyzing Change/Gain

Scores,(online),(http://www.p hysics.

indiana.edu/ sdi/AnalyzingCh

ange-Gain.pdf, diakses 18

Februari 2010)

Hakim. T (2000) Belajar secara Efektif . Jakarta : Puspa Suara

Jarot S- Darma dan A. Shenia, 2009.

Buku Pintar Menguasai Multimedia. Jakarta, Mediakita Multimedia,

Kwartolo Yuli, (2004). Teknologi Pembelajaran, Peningkatan Kualitas Belajar melalui Teknologi Pembelajaran. Pustekom dan Informasi Pendidikan, Jakarta
Nashar. (2004). Peraan Motivasi dan

Kemampuan Awal dalam

Kegiatan Pembelajaran.

Jakarta ; Delia Press.

Pandoyo. (1997). Strategi Belajar Mengajar. Semarang : IKIP Semarang Press.

Paul Suparno. (1997). Filsafat Konstruktivisme dalam Pendidikan. Yogyakarta : Kanisius.

Sadiman. (1984). Media Pendidikan Pengertian, Pengembangan dan Pemanfaatan. Jakarta : CV. Raja Wali.

Seels. (1979). Teknologi Pembelajaran Definisi dan Kawasannya. Jakarta : Unit Percetakan UNJ

Subana dan Sudrajat. (2005). Dasardasar Penelitia Ilmiah. Bandung : Pustaka Setia.

Subana dan Sudrajat. (2000). Statistik Penelitian. Bandung : Pustaka Setia.

Sugiyono. (2009). Metode Penelitian. Bandung : Alfabeta.

Suyanto, M. (2005). Multimedia. Yogyakarta : Andi Ofset. 